Vol. 2 No. 1 Januari 2021: Pages 38-52

Al-Ma'mun: Jurnal Kajian Kepustakawanan dan Informasi

Journal homepage: http://ejournal.iainpurwokerto.ac.id/index.php/jkki

e-ISSN 2746-0509, p-ISSN 2723-3596, DOI: doi.org/10.2409o/jkki.v2i1.450o

\title{
Studi Bibliometrik Menganalisis Produktivitas Pengarang dan Keusangan pada Jurnal Iklim
}

\author{
Rhoni Rodin'1, Nurul Choirunnisa ${ }^{2}$ \\ ${ }^{1}$ Fakultas Ushuluddin Adab dan Dakwah, Institut Agama Islam Negeri Curup, Indonesia \\ ${ }^{2}$ Fakultas Adab dan Humaniora, Universitas Islam Negeri Raden Fatah Palembang, Indonesia \\ ${ }^{1}$ rhoni.rodin@iaincurup.ac.id, ${ }^{2}$ choirunnisanurul.nc@gmail.com
}

\section{$A B S T R A C T$}

The purpose of this study was to determine the obsolescence and productivity of authors using Lotka's Law. The journals under study are journals with the same subject, namely the subject of climate. The author took a random sample from 2015-2019 from the journal portal Meteorology, Climatology and Geophysics, there were 10 climate journals that were sampled in this study. From the results of this study, the highest literature obsolescence rate was in 2018, amounting to 7 citation years or $87.5 \%$, meaning that the article is old in terms of the citation year due to new information in a document so that old information will decline and eventually one day it will not. used again. From the results of the above calculations, it can be found that the overall average value of the literature obsolescence rate in 2015-2019 with an average value is 62.32\%. And the number of authors in this study were 148 people in random selection in 2015-2019. Based on calculations with Lotka's law, it was found that the author productivity for every 1 article was $83.78 \%$ with 124 authors, $12.83 \%$ authors who produced 2 articles with 19 authors, authors who produced 3 articles were $2.03 \%$ with 3 authors, authors who produce 4 articles are $0.68 \%$ with 1 author, and authors who produce 5 articles are $0.68 \%$ with 1 author.

Keywords: bibliometric, climate journal, obsolescence, author productivity

\section{A B S T R A K}

Tujuan dari penelitian ini untuk mengetahui Keusangan dan Produktifitas Pengarang dengan menggunakan Hukum Lotka. Adapun jurnal yang diteliti merupakan jurnal dengan subjek yang sama yaitu subjek iklim. Penulis mengambil sampel secara acak yaitu dari tahun 2015-2019 dari portal jurnal Iklim Meteorologi Klimatologi dan Geofisika, terdapat 1o Jurnal Iklim yang dijadikan sampel pada penelitian ini. Dari hasil penelitian ini Tingkat keusangan literatur tertinggi pada tahun 2018 yaitu berjumlah 7 sitiran tahun atau $87,5 \%$ artinya bahwa artikel tersebut sudah tua dalam hal tahun sitirannya disebabkan adaya informasi baru dalam suatu dokumen sehingga informasi yang lama akan mengalami penurunan dan akhirnya suatu saat tidak digunakan lagi. Dari hasil perhitungan di atas dapat di cari nilai rata-rata keseluruhan tingkat keusangan literature tahun 2015-2019 dengan nilai rata-rata adalah 62,32\%. Dan jumlah pengarang pada penelitian ini sebanyak 148 orang dalam pemilihan acak pada tahun $2015-2019$. Berdasarkan perhitungan dengan hukum Lotka maka ditemukan bahwa produktivitas pengarang untuk setiap 1 artikel adalah 83,78\% dengan sebanyak 124 pengarang, pengarang yang menghasilkan 2 artikel sebanyak 12,83\% dengan 19 pengarang, pengarang yang menghasilkan 3 artikel sebanyak 2,03\% dengan 3 pengarang, pengarang yang menghasilkan 4 artikel sebanyak o,68\% dengan 1 pengarang, dan pengarang yang menghasilkan 5 artikel sebanyak o,68\% dengan 1 pengarang.

Kata Kunci: bibliometric, jurnal iklim, keusangan, produktivitas pengarang 


\section{A. PENDAHULUAN}

Sebuah karya tulis ilmiah adalah suatu karya tulis yang disusun berdasarkan pendekatan metode ilmiah (aplikasi dari metode ilmiah) yang ditujukan untuk kelompok pembaca tertentu dan disajikan menggunakan format tertentu yang baku (Azril Azahari, 2019). Beberapa karya tulis ilmiah biasanya ditulis oleh civitas akademika seperti dosen, penelitia dan mahasiswa itu sendiri dari Perguruan Tinggi. Karya tulis ilmiah yang dirangkum di sebuah jurnal bisa membantu penggunannya dalam mencari referensi yang termutakhir dan juga memberikan nilai serta pengetahuan baru bagi penelitian selanjutnya.

Keusangan (obsolescence) literatur merupakan kajian bibliometrika/ informetrika tentang penggunaan dokumen (literatur) yang berkaitan dengan umur suatu literatur. Sesungguhnya fenomena lahir, hidup dan mati bagi mahluk hidup, dapat pula diterapkan pada dokumen. Suatu dokumen dikatakan "lahir" pada saat dokumen itu diterbitkan. Kemudian dokumen dikatakan "hidup" selama dokumen itu dimanfaatkan. Pada akhirnya dokumen dikatakan "mati” pada saat tidak ada lagi yang menggunakan dokumen itu (Badollahi Mustafa, 2009).

Jika berbicara mengenai keusangan suatu literatur akan bersangkutan dengan keusangan dari sebuah dokumen. Keusangan dokumen dilihat dengan, jika sebuah dokumen jarang disitir maka dokumen tersebut sudah usang. Begitu pula sebaliknya, jika sebuah dokumen sering disitir dan digunkana maka dokumen tersebut belum usang. Oleh karena itu, tingkat keterpakaian sebuah dokumen juga mempengaruhi kemutakhiran dokumen.

Penurunan dan peningkatan kesahihan dokumen disebabkan oleh beberapa factor, yaitu: (1) informasi yang dimuat sahih, namun sudah terserap dalam karya berikutnya; (2) informasi yang dimuat masih sahih, namun sudah diganti oleh karya berikutnya; (3) informasi yang dimuat sahih, namun informasi tersebut berada dalam bidang yang makin kurang diminati ilmuwan; (4) informasi tersebut tidak dianggap sahih (Sulistiyo-Basuki, 1988). Keusangan suatu dokumen bisa dilihat dari beberapa faktor yang mempengaruhinya. jumlah penggunaan literatur, jumlah publikasi, dan jumlah penulis.

Rini mengatakan suatu dokumen dikatakan usang adalah apabila dokumen-dokumen terkendali yang sudah dinyatakan tidak berlaku lagi atau telah melampui masa simpan yang ditetapkan menurut kebutuhan masing-masing unit kerja (Rini Anggrainingsih, 2011).

Eksistensi pengarang pada suatu jurnal ilmiah menggambarkan produktivitas pengarang pada jurnal tersebut. Salah satu metode yang dapat digunakan untuk membahas produktivitas pengarang adalah metode bibliometrika. Bibliometrika merupakan suatu metode penelitian dalam bidang perpustakaan dan informasi yang menggunakan analisis kuantitatif dan statistik dalam menyelesaikan permasalahan (Sulistyo-Basuki, 2006).

Berkaitan dengan produktivitas penulis, dikemukakan oleh Lotka bahwa ada hubungan terbalik antara jumlah artikel yang ditulis dengan jumlah penulis yang menulis artikel (Lotka, 1926). Semakin banyak artikel yang ditulis, semakin sedikit penulis yang menulisnya.

Kajian mengenai keusangan (obsolescence) literatur yang termasuk dalam objek kajian ilmu informetrika/ bibliometrika belum banyak dilakukan di Indonesia. Hal ini karena fokus perpustakaan di Indonesia bukan dalam hal membuang koleksi yang tidak banyak digunakan, melainkan masih pada bagaimana menambah koleksi yang jumlah dan ragamnya masih terbatas dimiliki oleh perpustakaan di Indonesia pada umumnya (Badollahi Mustafa, 2009). 
Banyak penelitian yang telah dilakukan berkaitan dengan keusangan literature dan tingkat produktivitas pengarang ini. Muhamad Sopari dan Lidya Christiani misalnya, Berdasarkan hasil penelitiannya bahwa jenis literatur yang paling banyak digunakan adalah literatur primer yaitu sebesar 96,59\%. Buku merupakan bentuk literatur yang paling banyak disitir yakni sebesar $64,88 \%$. Usia o-9 tahun merupakan kelompok usia yang paling banyak disitir yaitu sebesar $53,88 \%$. Bahasa literatur yang paling banyak disitir adalah literatur berbahasa Indonesia sebesar 77,88\%. Nilai keusangan literatur yang disitir adalah 9 tahun. Persentase sebesar 53,38\% dari keseluruhan literatur yang disitir pada skripsi FIB Undip tahun 2015 berusia di bawah 9 tahun atau di bawah titik keusangan literature (M. Sopari, 2016).

Untuk keusangan literatur bidang pertanian periode tahun 2006-2012 penghitungan median tahun sitasinya berjumlah lebih dari 14 tahun, maka dapat diperkirakan bahwa literatur tersebut telah using (Nabila Ainun Nazifah, 2020). Lebih lanjut Putu Gede Krisna Yudhi Kartika yang melakukan penelitian terhadap Jurnal Skala Husada "The Journal of Health" merupakan jurnal dengan bidang subjek kesehatan masyarakat. Usia paro hidup tertinggi pada Jurnal Skala Husada "The Journal of Health" yaitu pada volume 11 Nomor 1 Tahun 2014 dengan usia paro hidup 7 tahun dan sitiran yang usang berjumlah 99 (49,7\%) dan sitiran valid 100 (50,3\%). Usia paro hidup terendah pada Jurnal Skala Husada "The Journal of Health" yaitu pada volume 11 Nomor 2 Tahun 2014 yaitu 3 tahun dan sitiran yang usang berjumlah 111 $(56,3 \%)$ dan sitiran valid 86 (43,7\%) (Putu Gede Krisna Yudhi Kartika, 2016).

Ada lagi satu penelitian yang mengkaji artikel Sosiologi dengan menggunakan kajian bibliometrika. Kajian bibliometrika terhadap artikel ini penting dilakukan untuk mengetahui perkembangan ilmu Sosiologi. Penelitian ini bertujuan untuk mengetahui keusangan, paro hidup, dan mengatahui hasil dalil zipf tahun 2015-2018. Dimana hasil penelitiannya menunjukkan bahwa paro hidup dalam artikel Sosiologi yang paling tinggi yaitu 24 tahun, dan dalil zipf dari artikel Sosiologi ini yang peringkat katanya tertinggi yaitu peringkat 11 dari artikel yang berjudul Perilaku Remaja Penggunaan Gadget: Analisis Sosiologi Teori Pendidikan (Rhoni Rodin dan Nur Afifah, 2019).

Oleh karena itu penulis tertarik untuk mengkaji mengenai Keusangan dan Produktifitas Pengarang. Karena dengan begitu kita bisa mengetahui nilai kemutakhiran dari suatu artikel atau jurnal, sehingga dapat dijadikan sebagai bahan rujukan. Berdasarkan uraian diatas penulis tertarik untuk meneliti dengan judul "Analisis Keusangan dan Produktivitas Pengarang Mengunakan Hukum Lotka Pada Jurnal Iklim”

\section{B. PROBLEM STATEMENT}

Dalam menentukan sebuah informasi untuk dijadikan bahan sebagai rujukan pada penelitian haruslah menggunakan literatur yang terbaru dan sering disitir oleh penelitipeneliti lainnya untuk mengetahui kemutakhiran literatur dan pertumbuhan literatur pada suatu bidang ilmu. Untuk mengetahui kemutakhiran dari suatu literature hendaknya mengetahui tingkat keusangan dari literature tersebut serta membantu perpustakaan untuk menyingkirkan koleksi-koleksi yang tidak terpakai lagi. 


\section{LITERATURE REVIEW}

\section{Keusangan Literatur}

Keusangan literatur (Obsolescence) adalah penurunan dalam menggunakan literatur atau kelompok literatur pada periode tertentu karena literatur-literatur tersebut menjadi lebih tua. Median umur sitiran (median citation age) yang termasuk obsolescence synchronous diukur dengan cara memeriksa tahun terbitan referensi literatur (S. Hartinah, 2002). Dengan adanya penghitungan median umur sitiran dapat mengetahui tahun keusangan dari sebuah lilteratur.

Keusangan literatur adalah kajian bibliometrika/informetrika tentang penggunaan dokumen (literatur) yang berkaitan dengan umur literatur tersebut. Sesungguhnya fenomena lahir, hidup dan mati bagi mahluk hidup, dapat pula diterapkan pada dokumen. Suatu dokumen dikatakan "lahir" pada saat dokumen itu diterbitkan. Kemudian dokumen dikatakan "hidup" selama dokumen itu dimanfaatakan. Pada akhirnya dokumen dikatakan "mati" pada saat tidak ada lagi yang menggunakan dokumen itu. Death of paper adalah konsep dalam ilmu informetrika/bibliometrika yang berarti bahwa suatu karya tidak pernah lagi dikutip (Badollahi Mustafa, 2009). Dengan adanya dokumen yang baru maka dokumen yang lama akan mengalami penurunan pemanfaatannya tetapi dapat dikatakan tetap hidup jika masih banyak yang menyitir ataupun memanfaatkan suatu literatur.

Penurunan dan peningkatan kesahihan dokumen disebabkan oleh beberapa faktor, yaitu :

a. Informasi yang dimuat sahih, namun sudah terserap dalam karya berikutnya;

b. Informasi yang dimuat masih sahih, namun sudah diganti oleh karya berikutnya;

c. Informasi yang dimuat sahih, namun informasi tersebut berada dalam bidang yang makin kurang diminati ilmuan;

d. Informasi tersebut tidak dianggap sahih (Sulistyo-Basuki, 1988).

Dari beberapa faktor tersebut dapat mempengaruhi keusangan literatur dan menyebabkan terjadinya penurunan penggunaan dokumen sehingga penulis harus mengikuti pertumbuhan suatu bidang ilmu.

Tak hanya untuk mengetahui tahun keusangan dari sebuah literatur, kajian literatur juga bermanfaat untuk efisiensi dalam bidang pengelolaan perpustakaan. karena hasil kajian keusangan literatur dapat digunakan untuk:

a. Penyiangan (weeding) koleksi yang tidak diperlukan lagi;

b. Pemanfaatan ruang/rak yang terbatas;

c. Pemisahan koleksi yang sering digunakan dan jarang digunakan;

d. Efektivitas pelayanan bagi pemustaka (Badollahi Mustafa, 2009).

\section{Produktivitas Pengarang Dengan Hukum Lotka}

Produktivitas penulis adalah banyaknya karya tulis yang dihasilkan oleh seseorang secara individual maupun secara kolaborasi dalam subjek tertentu dan diterbitkan pada jurnal-jurnal ilmiah baik dalam skala nasional maupun internasional dalam subjek tertent $u$ dengan kurun waktu tertentu. Produktivitas penulis disebut juga produktivitas ilmiah, 
produktivitas ilmiah menunjukkan jumlah publikasi ilmiah baik yang terindeks maupun tidak terindeks secara nasional dan internasional (Lotka, 1926).

Produktivitas pengarang adalah banyaknya karya tulis yang dihasilkan oleh seseorang secara individual dalam subjek tertentu dan diterbitkan pada jurnal-jurnal ilmiah dalam subjek yang bersangkutan dalam kurun waktu tertentu (Mustangimah, 2002). Produktivitas pengarang ini disebut juga sebagai produktivitas ilmiah yang merupakan jumlah penelitian yang dihasilkan oleh para ilmuwan ditentukan berdasarkan jumlah kontribusi karya ilmiah dalam bidang tertentu (Virgil, 1994).

Dari beberapa definisi diatas dapat diambil kesimpulan bahwa produktivitas pengarang adalah banyknya karya tulis yang dihasilkan seseorang ataupun berkolaborasi dalam bidang tertentu dan diterbitkan pada jurnal-jurnal ilmiah dalam kurun waktu tertentu.

Salah satu metode yang dapat digunakan untuk membahas tingkat produktivitas pengarang adalah teknik bibliometrika. Bibliometrika adalah penggunaan metode matematika dan statistika terhadap pengukuran fenomena perbukuan dan media lainnya (Putu Laxman Pendit, 2003). Menurut Wofram dalam Pendit, hukum bibliometrika terdiri dari tiga dalil, yaitu dalil hukum Lotka, dalim hukum Bradford, dan dalil hukum Zipf. Untuk mengetahui produktivitas pengarang hukum Lotka merupakan hukum bibliometrik klasik yang berkaitan dengan tingkat produktivitas penulis artikel (Putu Laxman Pendit, 2003).

Hukum Lotka menggunakan rumus umum yang menunjukkan hubungan jumlah pengarang (y) menghasilkan sejumlah karya tertentu (x) kemudian disebut dengan hukum terbalik.

$$
y_{\mathrm{x}}=\frac{C}{x^{\mathrm{n}}}
$$

Untuk menentukan eksponen $n$ yaitu denngan menggunakan metode least squares dengan rumus :

$$
n=\frac{N \sum X Y-\sum X \cdot \sum Y}{N \sum X^{2}-\left(\sum X\right)^{2}}
$$

Keterangan :

$\mathrm{N}$ = banyak data yang diambil

$\mathrm{X}=\log \mathrm{x}$

$\mathrm{Y}=\log \mathrm{y}$

Untuk menentukan konstanta C yaitu dengan rumus (Ana Andres, 2010):

$$
C=\frac{1}{\sum \frac{1}{x^{n}}}
$$

\section{RESEARCH METHODS/ SUMMARY}

Penelitian ini menggunakan metode penelitian deskriptif dengan pendekatan kuantitatif yaitu metode yang berlandaskan pada filsafat positivisme, digunakan untuk meneliti pada populasi atau sampel tertentu, pengumpulan data menggunakan instrumen penelitian, analisis data bersifat kuantitatif (Sugiyono, 2012). Analisis data dari beberapa jurnal lalu dihitung menggunakan perhitungan khusus sehingga dapat menggambarkan dari data yang diperoleh. 


\section{E. RESULTS AND DISCUSSION/ CRITIQUE}

\section{Tingkat Keusangan Literatur}

Untuk menghitung usia paro hidup dan keusangan literatur yang disitir dari jurnal Iklim Meteorologi Klimatologi dan Geofisika Tahun 2015-2019 yang berjumlah 10 artikel, perhitungan dilakukan dengan cara pertahun yang dimulai dengan tahun 2015 terdapat 2 artikel, tahun 2017 terdapat 2 artikel, tahun 2018 terdapat 3 artikel, dan tahun 2019 terdapat 3 artikel.

\section{Perhitungan Tingkat Keusangan}

"Prediksi Curah Hujan Bulanan Menggunakan Principal Component Regression dan SST EOF Indonesia di Stasiun Klimatologi Negara - Bali” tahun 2015

\begin{tabular}{|c|c|c|}
\hline Tahun Terbit & Frekuensi Sitiran & Keusangan \\
\hline 2011 & I & \multirow{4}{*}{ 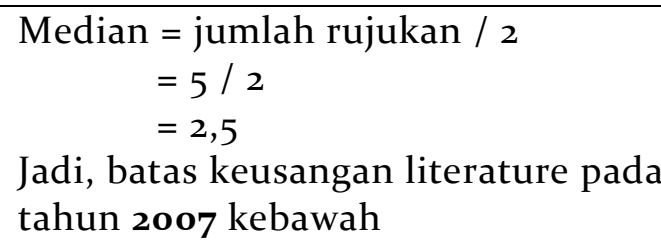 } \\
\hline 2007 & II & \\
\hline 2006 & I & \\
\hline 2004 & I & \\
\hline
\end{tabular}

Sumber: Diolah dari penulis

"Analisis Kemuculan Awan Hujan Berdasarkan Jenisnya untuk Mendukung Kegiatan Modifikasi Cuaca" tahun 2015

\begin{tabular}{|c|c|c|}
\hline Tahun Terbit & Frekuensi Sitiran & Keusangan \\
\hline 2015 & I & \multirow{6}{*}{$\begin{array}{l}\text { Median }=\text { jumlah rujukan } / \mathbf{2} \\
\qquad \begin{aligned} & =7 / 2 \\
& =3,5\end{aligned} \\
\text { Jadi, batas keusangan literature pada } \\
\text { tahun } 2 \mathbf{0 1 1} \text { kebawah }\end{array}$} \\
\hline 2014 & I & \\
\hline 2013 & $\mathrm{I}$ & \\
\hline 2011 & II & \\
\hline 2006 & I & \\
\hline 2001 & I & \\
\hline
\end{tabular}

Sumber: Diolah dari penulis

“Analisis Siklon Tropis Nock-Ten Berbasis Data Satelit Himawari” tahun 2017

\begin{tabular}{|c|c|c|}
\hline Tahun Terbit & Frekuensi Sitiran & Keusangan \\
\hline 2017 & I & \multirow{7}{*}{$\begin{array}{l}\text { Median }=\text { jumlah Rujukan } / 2 \\
\qquad \begin{aligned} 2 \\
\quad=4\end{aligned} \\
\text { Jadi, batas keusangan literatur terjadi } \\
\text { pada tahun } \mathbf{2 0 0 7} \text { kebawah }\end{array}$} \\
\hline 2015 & II & \\
\hline 2007 & I & \\
\hline 2003 & $\mathrm{I}$ & \\
\hline 1998 & I & \\
\hline 1988 & I & \\
\hline 1975 & $\mathrm{I}$ & \\
\hline
\end{tabular}

Sumber: Diolah dari penulis 
“Pengamatan Kejadian Hujan dengan Disdrometer dan Micro Rain Radar di Serpong” tahun

\begin{tabular}{|c|c|c|}
\hline \multicolumn{3}{|c|}{2017} \\
\hline Tahun Terbit & Frekuensi Sitiran & Keusangan \\
\hline 2016 & $\mathrm{~V}$ & \multirow{6}{*}{ 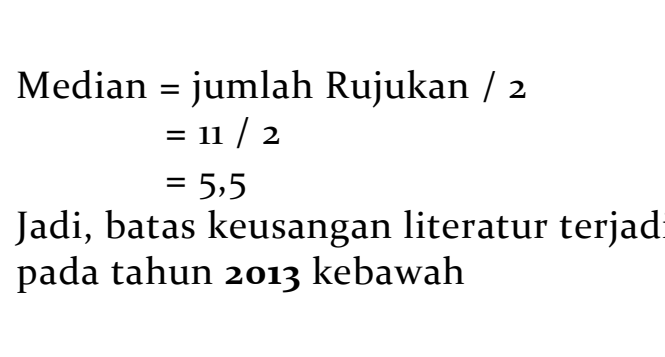 } \\
\hline 2013 & I & \\
\hline 2008 & I & \\
\hline 2005 & II & \\
\hline 2002 & $\mathrm{I}$ & \\
\hline 2000 & I & \\
\hline
\end{tabular}

Sumber: Diolah dari penulis

“Analisis Rawan Kekeringa Lahan Padi Kabupaten Banyuwangi Jawa Timur" tahun 2018

\begin{tabular}{|c|c|c|}
\hline Tahun Terbit & Frekuensi Sitiran & \multicolumn{1}{c|}{ Keusangan } \\
\hline 1996 & I & $\begin{array}{r}\text { Median }=\text { jumlah Rujukan / } 2 \\
=5 / 2 \\
=2,5\end{array}$ \\
\cline { 1 - 2 } 1982 & I & $\begin{array}{c}\text { Jadi, batas keusangan literatur terjadi } \\
\text { pada tahun } 1976 \text { kebawah }\end{array}$ \\
\hline 1976 & I & \\
\hline 1968 & I & I \\
\hline 1957 & &
\end{tabular}

Sumber: Diolah dari penulis

“Analisis Cuaca Ekstrem Terkait Bencana Hidrometeorologi di Jayapura (Studi Kasus Hujan Lebat Tanggal 22 Februari 2014)" tahun 2018

\begin{tabular}{|c|c|c|}
\hline Tahun Terbit & Frekuensi Sitiran & Keusangan \\
\hline 2015 & $\mathrm{I}$ & \multirow{4}{*}{$\begin{array}{l}\text { Median }=\text { jumlah Rujukan } / 2 \\
\qquad \begin{aligned} & \\
&=8 / 2 \\
&=4\end{aligned} \\
\text { Jadi, batas keusangan literatur terjadi } \\
\text { pada tahun } \mathbf{2 0 1 2} \text { kebawah }\end{array}$} \\
\hline 2012 & $\bar{V}$ & \\
\hline 2010 & I & \\
\hline 2006 & I & \\
\hline
\end{tabular}

Sumber: Diolah dari penulis

“Dampak Siklon Tropis Frances Terhadap Upwelling Laut Timor dan Sekitarnya” tahun 2018

\begin{tabular}{|c|c|c|}
\hline Tahun Terbit & Frekuensi Sitiran & \multicolumn{1}{c|}{ Keusangan } \\
\hline 2017 & II & $\begin{array}{r}\text { Median }=\text { jumlah Rujukan / } 2 \\
=5 / 2 \\
=2,5\end{array}$ \\
\cline { 1 - 2 } 2015 & I & $\begin{array}{l}\text { Jadi, batas keusangan literatur terjadi } \\
\text { pada tahun 2015 kebawah }\end{array}$ \\
\hline 2013 & I & I \\
\hline 2009 & &
\end{tabular}

Sumber: Diolah dari penulis

“Analisa Harmonic Pasang Surut dengan Metode Admiralty pada Stasiun Berjarak Kurang dari $50 \mathrm{Km}$ " tahun 2019

\begin{tabular}{|c|c|c|}
\hline Tahun Terbit & Frekuensi Sitiran & Keusangan \\
\hline 2018 & I & Median = jumlah Rujukan / 2 \\
\hline
\end{tabular}


Studi Bibliometrik Menganalisis Produktivitas Pengarang dan Keusangan pada Jurnal Iklim

\begin{tabular}{|c|c|c|}
\hline Tahun Terbit & Frekuensi Sitiran & Keusangan \\
\hline 2017 & I & $=3 / 2$ \\
$=1,5$
\end{tabular}

Sumber: Diolah dari penulis

"Potensi Panas Laut Sebagai Energi Baru Terbarukan di Perairan Papua Barat dengan Metode Ocean Thermal Energy Conversion (OTEC)" tahun 2019

\begin{tabular}{|c|c|c|}
\hline Tahun Terbit & Frekuensi Sitiran & Keusangan \\
\cline { 1 - 2 } 2018 & I & $\begin{array}{c}\text { Median }=\text { jumlah Rujukan } / 2 \\
=9 / 2 \\
=4,5\end{array}$ \\
\cline { 1 - 2 } 2017 & II & $\begin{array}{c}\text { Jadi, batas keusangan literatur terjadi } \\
\text { pada tahun 2014 kebawah }\end{array}$ \\
\hline 2016 & I & \\
\hline 2014 & II & \\
\hline 2012 & I & \\
\hline 2007 & II &
\end{tabular}

Sumber: Diolah dari penulis

"Estimasi Stok Karbon Menggunakan Spectral Band 6 Citra Landsat 8 pada Kawasan Mangrove di Sungai Tallo, Kota Makassar Sulawesi Selatan Tahun 2018” tahun 2019

\begin{tabular}{|c|c|c|}
\hline Tahun Terbit & Frekuensi Sitiran & Keusangan \\
\hline 2017 & $\mathrm{I}$ & \multirow{8}{*}{$\begin{array}{l}\text { Median }=\text { jumlah Rujukan } / 2 \\
\qquad \begin{array}{l}\quad 8 / 2 \\
=4\end{array} \\
\text { Jadi, batas keusangan literatur terjadi } \\
\text { pada tahun } 2012 \text { kebawah }\end{array}$} \\
\hline 2016 & I & \\
\hline 2015 & $\mathrm{I}$ & \\
\hline 2012 & I & \\
\hline 2011 & I & \\
\hline 2005 & I & \\
\hline 2004 & I & \\
\hline 1998 & I & \\
\hline
\end{tabular}

Sumber: Diolah dari penulis

\section{Rekapitulasi Tingkat Keusangan Literatur}

\begin{tabular}{|c|c|c|c|c|}
\hline No. & Tahun & Frekuensi Sitiran & $\begin{array}{c}\text { Frekuensi Sitiran yang } \\
\text { Usang }\end{array}$ & $\begin{array}{c}\text { Tingkat Keusangan } \\
(\%)\end{array}$ \\
\hline 1 & 2015 & 5 & 3 & $60 \%$ \\
\hline 2 & 2015 & 7 & 4 & $57,14 \%$ \\
\hline 3 & 2017 & 8 & 5 & $62,5 \%$ \\
\hline 4 & 2017 & 11 & 6 & $54,55 \%$ \\
\hline 5 & 2018 & 5 & 3 & $60 \%$ \\
\hline 6 & 2018 & 8 & 7 & $87,5 \%$ \\
\hline 7 & 2018 & 5 & 3 & $60 \%$ \\
\hline
\end{tabular}




\begin{tabular}{|c|c|c|c|c|}
\hline No. & Tahun & Frekuensi Sitiran & $\begin{array}{c}\text { Frekuensi Sitiran yang } \\
\text { Usang }\end{array}$ & $\begin{array}{c}\text { Tingkat Keusangan } \\
(\%)\end{array}$ \\
\hline 8 & 2019 & 9 & 5 & $55,56 \%$ \\
\hline 9 & 2019 & 3 & 2 & $66,67 \%$ \\
\hline 10 & 2019 & 8 & 5 & $62,5 \%$ \\
\hline \multicolumn{2}{r|}{ Total } & 69 & 43 & $62,32 \%$ \\
\hline
\end{tabular}

Sumber: Diolah dari penulis

Tingkat keusangan literature tertinggi pada tahun 2018 yaitu berjumlah 7 sitiran tahun atau $87,5 \%$ artinya bahwa artikel tersebut sudah tua dalam hal tahun sitirannya disebabkan adanya informasi baru dalam suatu dokumen sehingga informasi yang lama akan mengalami penurunan dan akhirnya suatu saat tidak digunakan lagi. Dari hasil perhitungan di atas dapat di cari nilai rata-rata keseluruhan tingkat keusangan literature tahun 2015-2019 dengan nilai rata-rata adalah $62,32 \%$.

Rumus umum yang menunjukkan hubungan jumlah pengarang (y) menghasilkan sejumlah karya tertentu (x) kemudian disebut dengan hukum terbalik.

$$
y_{x}=\frac{C}{x_{n}}
$$

Untuk menentukan eksponen n Menggunakan metode least squares rumusnya:

$$
x=\frac{N \sum X Y-\sum X \sum Y}{N \sum X^{2}-\left(\sum X\right)^{2}}
$$

$\mathrm{N}$ = banyak data yang diambil

$\mathrm{X}=\log \mathrm{X}$

$\mathrm{Y}=\log \mathrm{y}$

Untuk menentukan konstanta c yaitu dengan rumus (Andres, 2010):

$$
C=\frac{1}{\sum \frac{1}{X^{N}}}
$$

Pada uraian ini memuat peringkat pertama sampai peringkat terkahir penulis dalam menghasilkan artikel ilmiah. Tabel di bawah berisi sebanyak 148 pengarang yang diukur secara individu menghasilkan paling sedikit 1 sampai 5 artikel selama tahun 2015 sampai dengan tahun 2019.

\begin{tabular}{|c|c|l|c|}
\hline No & Peringkat & \multicolumn{1}{|c|}{ Nama Penulis } & $\begin{array}{c}\text { Jumlah Artikel yang } \\
\text { Dihasilkan }\end{array}$ \\
\hline 1 & I & Renggono Findy & 6 \\
\hline 2 & II & Supriyono & 4 \\
\hline 3 & III & Marzuki & 3 \\
\hline 4 & III & Hashiguchi H. & 3 \\
\hline 5 & III & E.L. Siadari & 3 \\
\hline 6 & IV & Aldrian E. & 2 \\
\hline 7 & IV & Estiningtyas W. & 2 \\
\hline 8 & IV & Emanuel K. & 2 \\
\hline 9 & IV & Gray W. M. & 2 \\
\hline
\end{tabular}




\begin{tabular}{|c|c|c|c|}
\hline 10 & IV & Dvorak V. F. & 2 \\
\hline 11 & IV & Vonnisa M. & 2 \\
\hline 12 & IV & Shimomai T. & 2 \\
\hline 13 & IV & Peters G. & 2 \\
\hline 14 & IV & Fischer B. & 2 \\
\hline 15 & IV & Tang D. L. & 2 \\
\hline 16 & IV & Fukao S. & 2 \\
\hline 17 & IV & Yamanaka M. D. & 2 \\
\hline 18 & IV & Ogino S. Y. & 2 \\
\hline 19 & IV & Okamoto N. & 2 \\
\hline 20 & IV & Murata F. & 2 \\
\hline 21 & IV & Sitorus B. P. & 2 \\
\hline 22 & IV & Kudsy M. & 2 \\
\hline 23 & IV & Kartasasmita M. & 2 \\
\hline 24 & IV & Ibrahim G. & 2 \\
\hline $25-124$ & $\mathrm{~V}$ & $\begin{array}{l}\text { Semua Penulis yang ditemukan } \\
\text { jumlahnya } 1\end{array}$ & 1 \\
\hline
\end{tabular}

Sumber: Diolah dari penulis

Dari table di atas dapat dilihat bahwa penulis yang paling produktif dalam menghasilkan artikel selama kurun waktu tersebut adalah Renggono Findy yang menghasilkan 6 artikel. Kemudia pada peringkat kedua ada 1 orang yaitu Supriyono yang menghasilkan 4 artikel. Lalu pada peringkat kedua ada 3 penulis yaitu Marzuki, Hashiguchi H., dan E.L. Siadari yang menghasilkan 3 artikel. Dan di peringkat ketiga ada 19 penulis dengan menghasilkan masing-masing 2 artikel. Serta beberapa penulis lainnya yang masingmasing penulis menghasilkan 1 artikel.

Kemudian judul artikel yang dihasilkan oleh 5 peringkat pertama pengarang. Tabel tersebut merupakan perwakilan dari 72 judul artikel yang dihasilkan selama tahun 2015 sampai dengan 2019

\begin{tabular}{|c|c|c|}
\hline No & Penulis & Judul Artikel \\
\hline \multirow[t]{5}{*}{1} & \multirow[t]{5}{*}{ Renggono Findy } & $\begin{array}{l}\text { 1. Precipitating Clouds Observed by } 1.3-\mathrm{GHz} \text { Boundary } \\
\text { Layer Radars in Equatorial Indonesia. }\end{array}$ \\
\hline & & 2. Pola Sebaran Hujan di Das Larona \\
\hline & & $\begin{array}{l}\text { 3. Pengaruh ENSO terhadap Pola Angin dan Curah Hujan } \\
\text { di DAS Larona, Sulawesi Selatan }\end{array}$ \\
\hline & & $\begin{array}{l}\text { 4. Analisis Awan Hujan pada Saat Banjir DKI dengan C- } \\
\text { band Radar }\end{array}$ \\
\hline & & $\begin{array}{l}\text { 5. Analisis Karakteristik Hujan dengan Disrometer } \\
\text { 6. - }\end{array}$ \\
\hline 2 & Supriyono & $\begin{array}{l}1 .- \\
2 .- \\
3 .- \\
4 .-\end{array}$ \\
\hline
\end{tabular}




\begin{tabular}{|c|c|c|}
\hline No & Penulis & Judul Artikel \\
\hline \multirow[t]{3}{*}{3} & \multirow[t]{3}{*}{ Marzuki } & $\begin{array}{l}\text { 1. Estimation of Raindrop Size Distribution Parameters } \\
\text { Using Rain Attenuation Data from a Ku-Band } \\
\text { Communications Satellite }\end{array}$ \\
\hline & & $\begin{array}{l}\text { 1. Intraseasonal Variation of Raindrop Size Distribution at } \\
\text { Koto Tabang, West Sumatra, Indonesia }\end{array}$ \\
\hline & & $\begin{array}{l}\text { 2. Performance Evaluation of Micro Rain Radar Over } \\
\text { Sumatra Through Comparison with Disdrometer and } \\
\text { Wind Profiler }\end{array}$ \\
\hline \multirow[t]{3}{*}{4} & \multirow[t]{3}{*}{ Hashiguchi H. } & $\begin{array}{l}\text { 1. Performance Evaluation of Micro Rain Radar Over } \\
\text { Sumatra Through Comparison with Disdrometer and } \\
\text { Wind Profiler }\end{array}$ \\
\hline & & $\begin{array}{l}\text { 2. Precipitating Clouds Observed by } 1.3-\mathrm{GHz} \text { Boundary } \\
\text { Layer Radars in Equatorial Indonesia }\end{array}$ \\
\hline & & 3. - \\
\hline 5 & Dst................... & \\
\hline
\end{tabular}

Sumber: Diolah dari penulis

Terdapat 19 penulis yang menghasilkan 2 artikel dan Lebih dari setengah penulis menghasilkan hanya 1 artikel yaitu sebanyak 103 penulis selama tahun 2015 sampai dengan 2019. Persentase jumlah penulis dalam menghasilkan artikel ilmiah pada jurnal Meteorologi Klimatologi dan Geofisika selama kurun waktu tersebut dapat dilihat pada tabel dibawah dengan menggunakan rumus persentase: $\mathrm{P}=\mathrm{f} / \mathrm{N}$ x $100 \%$

\begin{tabular}{|c|c|c|}
\hline Jumlah Penulis & Jumlah Artikel yang Dihasilkan & Presentase \\
\hline 124 & 1 & $83,78 \%$ \\
\hline 19 & 2 & $12,83 \%$ \\
\hline 3 & 3 & $2,03 \%$ \\
\hline 1 & 4 & $0,68 \%$ \\
\hline 1 & 6 & $0,68 \%$ \\
\hline 148 & & $100 \%$ \\
\hline
\end{tabular}

Sumber: Diolah dari penulis

Pengarang Yang Sering Disitir Nama-nama pengarang yang telah diurutkan pada pengolahan untuk mengetahui tingkat produktivitas pengarang digunakan sebagai acuan dalam mengidentifikasi pengarang yang sering disitir oleh pengarang lainnya dalam menghasilkan artikel pada setiap jurnal. Hanya pengarang individu dan pengarang kolaborasi yang namanya pertama sekali disebut dalam menghasilkan artikel ilmiah yang akan dilihat jumlah disitirnya mereka oleh pengarang lain pada masing-masing jurnal. Pengarang-pengarang yang paling sering disitir antar sesama pengarang selama kurun tahun 2015 sampai dengan 2019.

\begin{tabular}{|c|l|c|c|c|c|}
\hline $\begin{array}{c}\text { N } \\
\text { o }\end{array}$ & \multicolumn{1}{|c|}{$\begin{array}{c}\text { Nama Pengarang yang } \\
\text { Disitir }\end{array}$} & $\begin{array}{c}\text { Jumlah Artikel } \\
\text { yang Dihasilkan }\end{array}$ & $\begin{array}{c}\text { Nama Pengarang } \\
\text { yang Menyitir }\end{array}$ & $\begin{array}{c}\text { Frekue } \\
\text { nsi }\end{array}$ & Jumlah \\
\hline 1 & Renggono Findy & 6 & - & - & - \\
\hline 2 & Supriyono & 4 & - & - & - \\
\hline 3 & Marzuki & 3 & - & - & - \\
\hline 4 & Hashiguchi H. & 3 & - & - & - \\
\hline
\end{tabular}

47 A l-Ma'mun: Jurnal Kajian Kepustakawanan dan Informasi 
Studi Bibliometrik Menganalisis Produktivitas Pengarang dan Keusangan pada Jurnal Iklim

\begin{tabular}{|c|c|c|c|c|c|}
\hline $\begin{array}{l}\mathrm{N} \\
\mathrm{O}\end{array}$ & $\begin{array}{c}\text { Nama Pengarang yang } \\
\text { Disitir }\end{array}$ & $\begin{array}{c}\text { Jumlah Artikel } \\
\text { yang Dihasilkan }\end{array}$ & $\begin{array}{c}\text { Nama Pengarang } \\
\text { yang Menyitir }\end{array}$ & $\begin{array}{c}\text { Frekue } \\
\text { nsi }\end{array}$ & Jumlah \\
\hline 5 & E.L. Siadari & 3 & - & - & - \\
\hline 6 & Aldrian E. & 2 & - & - & - \\
\hline 7 & Estiningtyas W. & 2 & - & - & - \\
\hline 8 & Emanuel K. & 2 & - & - & - \\
\hline 9 & Gray W. M. & 2 & - & - & - \\
\hline 10 & Dvorak V. F. & 2 & - & - & - \\
\hline 11 & Vonnisa M. & 2 & - & - & - \\
\hline 12 & Shimomai T. & 2 & - & - & - \\
\hline 13 & Peters G. & 2 & - & - & - \\
\hline 14 & Fischer B. & 2 & - & - & - \\
\hline 15 & Tang D. L. & 2 & - & - & - \\
\hline 16 & Fukao S. & 2 & - & - & - \\
\hline 17 & Yamanaka M. D. & 2 & - & - & - \\
\hline 18 & Ogino S. Y. & 2 & - & - & - \\
\hline 19 & Okamoto N. & 2 & - & - & - \\
\hline 20 & Murata F. & 2 & - & - & - \\
\hline 21 & Sitorus B. P. & 2 & - & - & - \\
\hline 22 & Kudsy M. & 2 & - & - & - \\
\hline 23 & Kartasasmita M. & 2 & - & - & - \\
\hline 24 & Ibrahim G. & 2 & - & - & - \\
\hline 25 & Dst... & & & & \\
\hline
\end{tabular}

Sumber: Diolah dari penulis

Tabel di atas menunjukkan bahwa dari hasil perhitungan jumlah pengarang yang disitir oleh penulis lain. Tetapi kenyataannya semua pengarang di atas tidak disitir oleh pengarang lainnya dalam artikel yang mereka hasilkan.

\section{Pengujian Hukum Lotka Pada Pola Produktivitas}

Penulis telah menghimpun seluruh artikel masing-masing jurnal sejak tahun 2015 sampai dengan tahun 2019. Sehingga jumlah seluruh artikel yang dijadikan sampel sebanyak sebanyak 72 artikel dengan jumlah penulis sebanyak 148 penulis. Kemudian data yang telah dikumpulkan diujikan menggunakan persamaan kuadrad terbalik dari hukum Lotka yaitu: $y_{x} \cdot x^{n}=c$ Dimana $\mathrm{x}$ merupakan banyaknya artikel yang ditulis oleh penulis secara individual, y merupakan banyaknya penulis yang memberikan kontribusi sebanyak x artikel, dan c adalah konstanta. Menghitung distribusi produktivitas dapat dilakukan setelah menentukan nilai-nilai elemen dalam persamaan tersebut yaitu nilai $\mathrm{n}$ dan nilai c.

\begin{tabular}{|c|c|c|c|c|c|c|}
\hline $\boldsymbol{I}$ & $\boldsymbol{x}$ & $\boldsymbol{Y}$ & $\boldsymbol{X}=\boldsymbol{L o g} \boldsymbol{x}$ & $\boldsymbol{Y}=\log \boldsymbol{y}$ & $\mathbf{X Y}$ & $\boldsymbol{x}^{\mathbf{2}}$ \\
\hline 1 & 6 & 1 & 0,7782 & 0,0000 & 0,0000 & 0,6056 \\
\hline 2 & 4 & 1 & 0,6021 & 0,0000 & 0,0000 & 0,3625 \\
\hline 3 & 3 & 3 & 0,4771 & 0,4771 & 0,2276 & 0,2276 \\
\hline
\end{tabular}

Al-Ma'mun: Jurnal Kajian Kepustakawanan dan Informasi |48 


\begin{tabular}{|c|c|c|c|c|c|c|}
\hline$I$ & $x$ & $Y$ & $X=\log x$ & $Y=\log y$ & $\mathbf{X Y}$ & $x^{2}$ \\
\hline 4 & 2 & 19 & 0,3010 & 1,2787 & 0,3849 & 0,0906 \\
\hline 5 & 1 & 124 & 0,0000 & 2,0934 & 0,0000 & 0,0000 \\
\hline \multicolumn{2}{|c|}{ Total } & 148 & 2,1584 & 3,8492 & 0,6125 & 1,2863 \\
\hline
\end{tabular}

Sumber: Diolah dari penulis

Dalam menentukan nilai n digunakan persamaan berikut:

$b=\frac{\mathrm{N} \sum X Y-\sum X \sum Y}{N \sum X^{2}-\left(\sum X\right)^{2}}$

$b=\frac{5 \cdot 0,6125-(2,1584)(3,8492)}{5 \cdot 1,2863-2,1584^{2}}$

$b=\frac{3,0625-8,3081}{6,4315-4,6586}$

$b=\frac{-5,2456}{1,7729}$

$b=-2,9587$

Karena $\mathrm{b}=-\mathrm{n}$, maka $\mathrm{n}=\mathbf{2 , 9 5 8 7}$

Tabel Distribusi Frekuensi dengan n = 2,9587

\begin{tabular}{|c|c|c|c|c|}
\hline No & $\mathbf{x}$ & $\mathbf{y}$ & $\boldsymbol{x}^{\boldsymbol{n}}$ & $\mathbf{1}_{/ \boldsymbol{x}^{\boldsymbol{n}}}$ \\
\hline 1 & $\mathbf{1}$ & $\mathbf{1 2 4}$ & $\mathbf{1}$ & $\mathbf{1}$ \\
\hline 2 & 2 & 19 & 7,7742 & 0,1286 \\
\hline 3 & 3 & 3 & 25,8023 & 0,0387 \\
\hline 4 & 4 & 1 & 60,4386 & 0,0165 \\
\hline 5 & 6 & 1 & $\mathbf{2 0 0 , 5 9 3 1}$ & 0,0050 \\
\hline \multicolumn{2}{|c|}{ Jumlah } & $\mathbf{2 9 5 , 6 0 8 2}$ & $\mathbf{1 , 1 8 8 8}$ \\
\hline
\end{tabular}

Sumber: Diolah dari penulis

Kemudian untuk menentukan nilai c maka ditentukan dengan menggunakan persamaan

$$
\begin{gathered}
c=\frac{1}{\sum \frac{1}{x^{n}}} \\
c=\frac{1}{1,1888} \\
c=0,8412
\end{gathered}
$$

Dari perhitungan di atas telah ditemukan bahwa nilai c adalah 0,8412 yang berarti bahwa jumlah pengarang dengan 1 artikel merupakan suatu ketetapan pada pola tertentu yaitu o,8412 atau o,0084\%. Kemudian dengan menggunakan hasil tersebut maka persamaan sebagai berikut:

$$
y_{x} \cdot x^{2,9587}=0,8412
$$

Dari persamaan di atas maka dapat diketahui bahwa distribusi frekuensi produktivitas pengarang hasil perhitungan pola produktivitas pengarang dengan menggunakan hukum Lotka, yang dapat dilihat pada tabel berikut: 
Pola Produktivitas Pengarang dengan menggunakan Hukum Lotka

$$
y_{x} \cdot x^{2,9587}=0,8412
$$

\begin{tabular}{|c|c|c|c|}
\hline No & $\mathbf{X}$ & $\mathbf{Y}$ & $\boldsymbol{Y}_{\boldsymbol{X}}$ \\
\hline 1 & 1 & 124 & 0,8412 \\
\hline 2 & 2 & 19 & 0,1082 \\
\hline 3 & 3 & 3 & 0,0326 \\
\hline 4 & 4 & 1 & 0,0139 \\
\hline 5 & 6 & 1 & 0,0041 \\
\hline \multicolumn{2}{|c|}{ Total } & $\mathbf{1 4 8}$ & $\mathbf{1 , 0 0 0 0}$ \\
\hline
\end{tabular}

Sumber: Diolah dari penulis

Dari tabel di atas dapat dibuat grafik sebagai berikut:

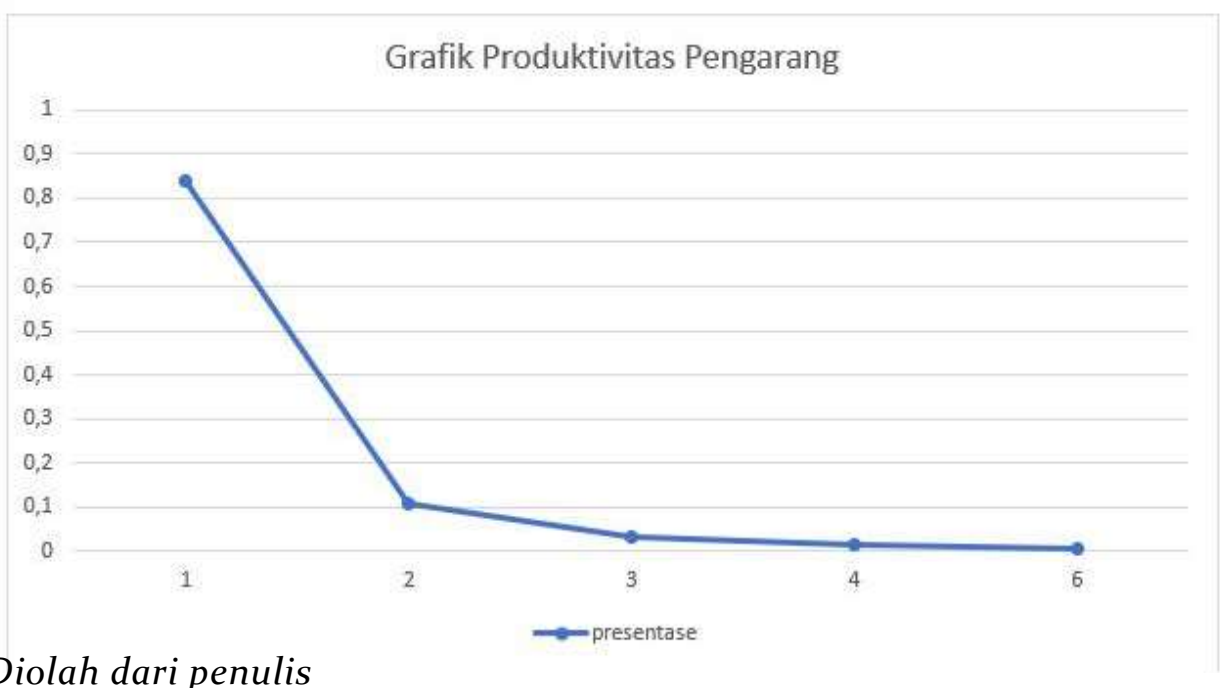

Sumber: Diolah dari penulis

Secara umum grafik di atas dapat memperlihatkan bahwa terdapat hubungan antara jumlah pengarang dan jumlah artikel yang dikarang seperti pada hukum Lotka. Makin kecil jumlah penulis maka makin banyak jumlah artikel yang ditulis.

Berdasarkan pemaparan hasil penelitian di atas, pada dasarnya penelitian ini memberikan kontribusi bagi yang positif para peneliti iklim meteorologi klimatologi dan geofisika. Karena penelitian ini akan menjadi rujukan bagi mereka dalam mencari referensi-referensi untuk penelitian mereka.

Disisi lain, penelitian ini berkontribusi bagi masyarakat dalam rangka untuk mengetahui bagaimana tingkat produktivitas penelitian dan penulisan di bidang iklim. Hasil penelitian ini akan menjadi bahan rujukan dan penilaian bagi masyarakat tentang bagaimana gambaran penulisan atau penelitian di bidang iklim.

\section{F. CONCLUSION}

Dari hasil penelitian ini Tingkat keusangan literatur tertinggi pada tahun 2018 yaitu berjumlah 7 sitiran tahun atau $87,5 \%$ artinya bahwa artikel tersebut sudah tua dalam hal tahun sitirannya disebabkan adaya informasi baru dalam suatu dokumen sehingga informasi yang lama 
akan mengalami penurunan dan akhirnya suatu saat tidak digunakan lagi. Dari hasil perhitungan di atas dapat di cari nilai rata-rata keseluruhan tingkat keusangan literature tahun 2015-2019 dengan nilai rata-rata adalah 62,32\%. Dan jumlah pengarang pada penelitian ini sebanyak 148 orang dalam pemilhan acak pada tahun 2015-2019. Berdasarkan perhitungan dengan hukum Lotka maka ditemukan bahwa produktivitas pengarang untuk setiap 1 artikel adalah 83,78\% dengan sebanyak 124 pengarang, pengarang yang menghasilkan 2 artikel sebanyak 12,83\% dengan 19 pengarang, pengarang yang menghasilkan 3 artikel sebanyak 2,03\% dengan 3 pengarang, pengarang yang menghasilkan 4 artikel sebanyak o,68\% dengan 1 pengarang, dan pengarang yang menghasilkan 5 artikel sebanyak o,68\% dengan 1 pengarang.

\section{DAFTAR PUSTAKA}

Ana Andres. (2010). Measuring Academic Research. Woodhead Publishing Limited.

Azril Azahari. (2019). Tehnik penulisan ilmiah. Universitas Terbuka. http://repository.ut.ac.id/4523/1/LUHT4353-M1.pdf

Badollahi Mustafa. (2009). Obsolescence: Mengenal Konsep Keusangan Literatur Dalam Dunia Kepustakawanan. IPB. http://keusangan-literatur-obsoslescence-2009.pdf

Lotka, A. J. (1926). The frequency distribution of scientific productivity. Journal of the Washington Academy of Sciences, 16, 317-323.

M. Sopari, and L. C. (2016). Karakteristik Dan Keusangan Literatur : Suatu Kajian Bibliometrik Pada Skripsi Fakultas Ilmu Budaya Universitas Diponegoro Tahun 2015. Jurnal Ilmu Perpustakaan, 5(4), 231-240.

Mustangimah. (2002). Distribusi frekuensi produktivitas penulis.

Nabila Ainun Nazifah. (2020). Keusangan Literatur, Paro Hidup, Dan Zipf Pada Artikel Bidang Pertanian. Jurnal Iqra', 14(1), 1-28.

Putu Gede Krisna Yudhi Kartika. (2016). Usia Paro Hidup Dan Keusangan Literatur Jurnal Skala Husada Volume 11, 12 Tahun 2014-2015. Jurnal D3 Ilmu Perpustakaan, 1(1).

Putu Laxman Pendit. (2003). Penelitian Ilmu Perpustakaan dan Informasi: Suatu Pengantar Diskusi Epistemologi dan Metodologi. JIP-FSUI.

Rhoni Rodin dan Nur Afifah. (2019). Studi bibliometrika pada abstrak artikel bidang ilmu sosiologi periode 2015-2018. Jurnal JUPITER, XVI(2), 1-30. https://journal.unhas.ac.id/index.php/jupiter/article/view/12871/6555

Rini Anggrainingsih. (2011). Analisa dan Perancangan Sistem Informasi Pengendalian Dokumen untuk Sistem Manajemen Mutu Standar ISO 9oo1. Seminar Nasional Teknologi Informasi $\mathcal{E} \quad$ Komunikasi Terapan 2011. http://eprints.dinus.ac.id/124/1/INF RM5_(INFR25_RiniAnggrainingsih_UNS).pdf

S. Hartinah. (2002). Keusangan dan paro hidup literatur. In Sulistyo-Basuki (Ed.). In Kumpulan makalah kursus bibliometrika. Masyarakat Informetrika Indonesia.

Sugiyono. (2012). Metode Penelitian Kuantitatif Kualitatif dan REDD. Alfabeta.

Sulistiyo-Basuki. (1988). Pengantar Ilmu Informasi: Buku Pedoman. Pusat antar Universitas Ilmu Komputer UI. 
Sulistyo-Basuki. (1988). Pengantar Ilmu Informasi: Buku Pedoman. Pusat antar Universitas Ilmu Komputer UI.

Sulistyo-Basuki. (2006). Perpustakaan dan Informasi dalam Konteks Sosial Budaya. Departemen llmu Perpustakaan \& lnformasi, FIB UI.

Virgil, D. (1994). Dictionary of bibliometrics. The Haworth Press, Inc. 